\title{
Recurrent Adamantinomatous Craniopharyngioma
}

National Cancer Institute

\section{Source}

National Cancer Institute. Recurrent Adamantinomatous Craniopharyngioma. NCI

Thesaurus. Code C162612.

The reemergence of adamantinomatous craniopharyngioma after a period of remission. 